\title{
Evaluation of Indigenous Potato Challisha (Solanum tuberosum L. Cv. Challisha) Somaclonals Tolerance to Salinity In Vitro
}

Md. Sanaullah Biswas *, Md. Riazul Islam, Mohammad Zakaria

Department of Horticulture, Bangabandhu Sheikh Mujibur Rahman Agricultural University, Gazipur-1706, Bangladesh

\section{ABSTRACT}

Potato is one of the most important food crops in the world. It is generally sensitive to salinity and likes to grow in neutral soil. On the other hand, salinity is increasing alarmingly in the ever changing climatic conditions. Thus, the selection of salt tolerant potato cultivars is necessary to keep pace the production of potato. To select salt tolerant cultivars, here we attempt to compare the salinity level between indigenous and modern cultivars. In vitro selection of local and modern potato cultivars were investigated with five levels of $\mathrm{NaCl}(0,30,60,90$ and $120 \mathrm{mM})$. The indigenous potato Challisha and modern cultivars Diamant and Felsina were used as plant materials. Significant differences were noticed among the cultivars in response to different levels of $\mathrm{NaCl}$. Plant growth and root development were gradually reduced with increased concentration of $\mathrm{NaCl}$. All three cultivars were survived well with exhibiting different growth status up to $60 \mathrm{mM} \mathrm{NaCl}$, but they performed poorly at $120 \mathrm{mM}$ of $\mathrm{NaCl}$. Culti var Challisha performed better regarding shoot length, root length, the number of nodes per plantlet and the fresh weight per plant up to $90 \mathrm{mM}$ of $\mathrm{NaCl}$. Thus, we can conclude that local indigenous variety Challisha is salt tolerant comparing with the modern cultivated varieties.

Keywords: Indigenous potato cultivars, salinity, tolerant

\section{INTRODUCTION}

Plants are regularly challenged by various biotic and environmental stresses in the natural environment [1]. Environmental stresses, such as drought, salinity, coldness, high temperature and heavy metals disturb the metabolism of plants. Salt stress is affecting the metabolism of plants and causes a modification in different biochemical and molecular processes which limit yield of crops [2]. Besides, plants can sense the changes of environmental conditions and regulate their gene expression to adjust their metabolism to survive. Generally, plants are stressed in three ways in saline soils; i) low water potential of the root medium leads water deficit, ii) the toxic effects of the $\mathrm{Na}+$ and $\mathrm{Cl}$ and iii) nutrient imbalance by depression in uptake and/or shoot transport [3, 4]. Toxic accumulation of $\mathrm{Na}+$ and $\mathrm{Cl}$ - in the leaves has also been correlated with stomatal closure and reduction of total chlorophyll content in leaves [5].

\section{*Corresponding author:}

Md. Sanaullah Biswas

Department of Horticulture, Bangabandhu Sheikh Mujibur

Rahman Agricultural University

Gazipur 1706, Bangladesh.

E-mail: sanaullahbiswas@gmail.com
Cell and tissue culture techniques together with conventional breeding and genetic engineering have been considered as the potential approaches for the development of plants with increased tolerance to environmental stresses [6]. The outstanding selection of mutant lines from cultured cells and the regeneration of whole plants from such cells have stimulated many attempts for the development of salt-tolerant plants [7]. A small number of potato genotypes have been reported in salinity tolerance under outdoor, greenhouse or in vitro conditions. Field trials $[8,9,10,11]$ and greenhouse pot trials were used to examine salinity tolerance genotype under $\mathrm{NaC} 1$ or sodium salt irrigation solutions based on either tuber yield [12, 13], a relative reduction of foliage dry weight [14] or haulm fresh weight [15]. Conventional screening methods for the development of salt tolerant variants are laborious and time-consuming [16]. Whereas in vitro screening of potato was used successfully against various about

\section{How to cite:}

Biswas MS, Islam MR, Zakaria M (2017) Evaluation of Indigenous Potato Challisha (Solanum tuberosum L. Cv. Challisha) Somaclonals Tolerance to Salinity In Vitro.

J. Trop. Life. Science 7 (1): 77-82. 
stresses. For example, sensitive and tolerant varieties of potato were screened under drought stress and found that var. Maxi was tolerant from the 18 tested varieties [17]. In vitro tested of 25 potato cultivars to salinity and found that 7 cultivars were tolerant and the remaining were sensitive [18]. Kroda potato variety showed salt tolerant among the 8 varieties screened out for salt tolerant [6]. To find out the tolerant salinity among the 10 potato varieties [19] Munira et al. (2015) found that Felsina was relatively salt tolerant, while Diamant was a moderately salt tolerant $[20,18]$. However, the local variety Challisha was not tested its tolerant to salinity in vitro compared with the other cultivated potato variety. For this purpose, the study was conducted to compare the salinity tolerant levels of the indigenous variety Challisha among the selected three potato cultivars.

Potato is glycophyte plant and classified as moderately salt tolerant to moderately salt sensitive compared with other crops [21]. Considerable salt stress resistances were found in the wild diploid Solanum potato relatives [7]. Despite the importance of potato, whole plant salt resistance mechanisms in diploid potato have not been extensively studied [22]. Selection of potato cultivars under different salt stress helps to develop an efficient screening technique of salinity resistant potato lines and to evaluate salt-tolerant cultivars effective for future use under salinity conditions [15]. Therefore, the main purpose of this study is to compare the salinity tolerant of the original cultivar in vitro compared with the modern potato varieties.

\section{MATERIALS AND METHODS}

\section{Plant material}

The potato varieties were collected from the Tuber Crop Research Centre of Bangladesh Agriculture Research Institute, Gazipur. The Institute morphologically characterized that Challisha $\left(\mathrm{V}_{1}\right)$ is a less cultivated local variety and Diamant $\left(\mathrm{V}_{2}\right)$ and, Felsina $\left(\mathrm{V}_{3}\right)$ are modern cultivated variety based on their yield performance.

\section{Tuber germination and explants preparation}

We made a slight modification of [6] Zaman et al. (2015) and [25] Rahman et al. (2008) for tuber germination and explant preparation. Surface sterilization of the 3 cultivars were maintained at room temperature under total darkness for sprouting. The shoot buds were removed from the sprouted tubers using a sterile surgical knife. Then surface sterilized with $5 \%$ sodium hypochlorite with a drop of Tween 20 for $15 \mathrm{~min}$. After
3-4 times washing in sterile distilled water, the shoot buds were treated with $70 \%$ ethyl alcohol for one minute and washed 3 times in sterile distilled water. The shoot meristems with a single node was isolated from the surface sterilized shoot buds under the laminar air flow cabinet.

\section{Media preparation}

Murashige and Skoog (1962) medium contained $3 \%$ sucrose and solidified with $0.8 \%$ agar and $\mathrm{pH}$ was adjusted at 5.8 [23]. The medium was adjusted to 5.8 and autoclaved at $121^{\circ} \mathrm{C}$ for $20 \mathrm{~min}$. All the cultures were incubated at $25 \pm 2^{\circ} \mathrm{C}$ with $16 / 8 \mathrm{~h} \mathrm{D} / \mathrm{N}$ cycle at the cool white fluorescent light [6].

\section{Salt stress treatments}

The levels of salt concentrations were selected from Murshed et al. (2015) with slight modifications [20]. Salt stress was assessed by transferring single nodes explant to medium containing five concentrations of $\mathrm{NaCl}$ (C0-0 mM, C1-30 mM, C2-60 mM, C3-90 mM and $\mathrm{C} 4-120 \mathrm{mM}$ ) with four replications. The experiment ended in four weeks, and the growth response was noted on the root length, the shoot length, the number of nodes, the number of leaves, the number of root and fresh weight.

\section{Statistical analysis}

The recorded data were analyzed statistically with the help of computer following STAT-C program. Mean separation was done by Duncan Multiple Range Test.

\section{RESULTS AND DISCUSSION}

The in vitro regenerated potato cultivars were screened after four weeks at different salt concentrations. The physiological characters including: root length, shoot length, root shoot length ratio, the number of nodes, the number of leaves, the number of roots and fresh weight were measured and presented in Table 1 and Figure 1.

The results shown in Figure 1 showed that variety Challisha produced longest shoot $(5.91 \mathrm{~cm})$ followed by Felsina $(2.97 \mathrm{~cm})$ while the Diamant produced shortest shoot $(2.12 \mathrm{~cm})$. Variety Challisha and Felsina performed better and statistically similar regarding root length while Diamant performed inferior. Challisha produced the maximum number of nodes (7.40) followed by Felsina (5.25) and Diamant (3.48). The similar trend was found in the number of leaves and the number of roots per plantlet. Fresh weight was the 
Table 1. Effect of different concentrations of $\mathrm{NaCl}$ on in vitro regeneration of three potato varieties

\begin{tabular}{cllllll}
\hline Levels of $\mathrm{NaCl}$ & Shoot length $(\mathrm{cm})$ & Root length $(\mathrm{cm})$ & $\begin{array}{c}\text { No. of nodes per } \\
\text { plantlet }\end{array}$ & $\begin{array}{c}\text { No. of leaves per } \\
\text { plantlet }\end{array}$ & $\begin{array}{c}\text { No. of roots per } \\
\text { plantlet }\end{array}$ \\
\hline $\mathrm{C}_{0}-0 \mathrm{mM}$ & $6.39 \mathrm{a}$ & $8.00 \mathrm{a}$ & $6.96 \mathrm{a}$ & $9.01 \mathrm{a}$ & $4.96 \mathrm{a}$ & $122.92 \mathrm{a}$ \\
$\mathrm{C}_{1}-30 \mathrm{mM}$ & $4.83 \mathrm{~b}$ & $5.84 \mathrm{~b}$ & $7.08 \mathrm{a}$ & $6.71 \mathrm{~b}$ & $3.17 \mathrm{~b}$ & $114.42 \mathrm{a}$ \\
$\mathrm{C}_{2}-60 \mathrm{mM}$ & $3.68 \mathrm{c}$ & $5.65 \mathrm{~b}$ & $6.21 \mathrm{a}$ & $5.98 \mathrm{~b}$ & $2.88 \mathrm{~b}$ & $104.00 \mathrm{ab}$ \\
$\mathrm{C}_{3}-90 \mathrm{mM}$ & $1.87 \mathrm{~d}$ & $4.33 \mathrm{~b}$ & $3.75 \mathrm{~b}$ & $4.42 \mathrm{c}$ & $2.04 \mathrm{~b}$ & $87.17 \mathrm{~b}$ \\
$\mathrm{C}_{4}-120 \mathrm{mM}$ & $1.55 \mathrm{~d}$ & $4.89 \mathrm{~b}$ & $2.88 \mathrm{~b}$ & $2.46 \mathrm{~d}$ & $1.92 \mathrm{~b}$ & $57.67 \mathrm{c}$ \\
\hline
\end{tabular}

Table 2. Interaction effect of cultivars and different concentrations of $\mathrm{NaCl}$ on in vitro regeneration potato

\begin{tabular}{|c|c|c|c|c|c|c|}
\hline $\begin{array}{c}\text { Interaction of Cultivars and } \mathrm{NaCl} \\
\text { (Treatment Combination) }\end{array}$ & Shoot length $(\mathrm{cm})$ & Root length $(\mathrm{cm})$ & $\begin{array}{l}\text { No. of nodes per } \\
\text { plantlet }\end{array}$ & $\begin{array}{c}\text { No. of leaves per } \\
\text { plantlet }\end{array}$ & $\begin{array}{l}\text { No. of roots per } \\
\text { plantlet }\end{array}$ & $\begin{array}{c}\text { Fresh weight } \\
\text { (mg) }\end{array}$ \\
\hline $\mathrm{V}_{1} \mathrm{C}_{0}$ & $9.48 \mathrm{a}$ & $7.56 \mathrm{abc}$ & $9.25 \mathrm{a}$ & $10.63 a$ & $7.13 \mathrm{a}$ & $144.25 \mathrm{a}$ \\
\hline $\mathrm{V}_{1} \mathrm{C}_{1}$ & $8.69 a$ & $5.59 \mathrm{bc}$ & $9.38 \mathrm{a}$ & $8.50 \mathrm{abc}$ & $3.75 b c$ & $138.25 \mathrm{ab}$ \\
\hline $\mathrm{V}_{1} \mathrm{C}_{2}$ & $6.41 \mathrm{~b}$ & $8.65 \mathrm{ab}$ & $8.25 \mathrm{ab}$ & $8.00 \mathrm{abc}$ & $4.00 \mathrm{bc}$ & $131.00 \mathrm{abc}$ \\
\hline $\mathrm{V}_{1} \mathrm{C}_{3}$ & $3.25 \mathrm{de}$ & $7.51 \mathrm{abc}$ & $6.68 \mathrm{abc}$ & $6.38 \mathrm{cde}$ & $3.50 \mathrm{bcd}$ & 107.25abcde \\
\hline $\mathrm{V}_{1} \mathrm{C}_{4}$ & $1.71 \mathrm{efg}$ & $6.38 \mathrm{bc}$ & 3.50cde & $3.50 \mathrm{fg}$ & $3.13 \mathrm{cde}$ & 79.75def \\
\hline $\mathrm{V}_{2} \mathrm{C}_{0}$ & $5.59 \mathrm{bc}$ & $8.08 \mathrm{ab}$ & $6.38 \mathrm{abc}$ & $7.13 \mathrm{bcd}$ & $4.88 \mathrm{ab}$ & 101.00abcde \\
\hline $\mathrm{V}_{2} \mathrm{C}_{1}$ & $1.74 \mathrm{efg}$ & 1.70de & 4.00cde & 4.50def & $2.25 \mathrm{bcde}$ & 93.75cde \\
\hline $\mathrm{V}_{2} \mathrm{C}_{2}$ & $1.73 \mathrm{efg}$ & $0.43 \mathrm{e}$ & $3.75 \mathrm{cde}$ & 3.63efg & $1.38 \mathrm{cde}$ & $86.25 \mathrm{def}$ \\
\hline $\mathrm{V}_{2} \mathrm{C}_{3}$ & $1.11 \mathrm{fg}$ & $0.98 \mathrm{e}$ & $2.25 \mathrm{de}$ & $2.38 \mathrm{fg}$ & $0.88 \mathrm{de}$ & $73.75 \mathrm{ef}$ \\
\hline $\mathrm{V}_{2} \mathrm{C}_{4}$ & $0.45 \mathrm{cg}$ & $0.80 \mathrm{e}$ & $1.00 \mathrm{e}$ & $1.00 \mathrm{~g}$ & $0.63 \mathrm{e}$ & $47.50 \mathrm{f}$ \\
\hline $\mathrm{V}_{3} \mathrm{C}_{0}$ & $4.11 \mathrm{~cd}$ & $8.38 \mathrm{ab}$ & $5.25 \mathrm{bcd}$ & $9.28 \mathrm{ab}$ & $2.88 \mathrm{bcde}$ & 123.50abcd \\
\hline $\mathrm{V}_{3} \mathrm{C}_{1}$ & $4.08 \mathrm{~cd}$ & $10.24 a$ & $7.88 \mathrm{ab}$ & $7.13 \mathrm{bcd}$ & $3.50 \mathrm{bcd}$ & 111.25abcde \\
\hline $\mathrm{V}_{3} \mathrm{C}_{2}$ & $2.90 \mathrm{df}$ & $7.88 \mathrm{abc}$ & $6.63 \mathrm{abc}$ & 6.31cde & $3.25 \mathrm{bcde}$ & 94.75bcde \\
\hline $\mathrm{V}_{3} \mathrm{C}_{3}$ & $1.25 \mathrm{efg}$ & $4.48 \mathrm{~cd}$ & $2.37 \mathrm{de}$ & 4.50def & $1.75 \mathrm{cde}$ & 80.50def \\
\hline $\mathrm{V}_{3} \mathrm{C}_{4}$ & 2.50defg & 7.49abc & 4.13cde & $2.88 \mathrm{fg}$ & $3.00 \mathrm{bcde}$ & $45.75 f$ \\
\hline
\end{tabular}

highest (120.10 mg) in Challisha, which was statistically superior to Felsina $(91.15 \mathrm{mg}$ ) followed by Diamant $(80.45 \mathrm{mg})$. The appearance of the variety also showed that Challisha and Felsina performed better compare to Diamant (Figure 2). Our results were in compliance with the findings of [6] Zaman et al. (2015) and [24] Aghaei et al. (2009) they reported that white potato is moderately salt tolerant and other tested varieties were salt sensitive. In vitro study also showed that internodes and tuber yield in potato were reduced at higher salt levels by Mahmoud et al. (2009) [25]. Etehadnia (2009) also studied details of potato performance under salt stress and found that salt stress affects plant growth and reduced yield which also supported our findings [16].

Different levels of $\mathrm{NaCl}$ had a significant effect on all growth parameters of potato (Figure 1). Most of the parameters decreased gradually with the increase of
$\mathrm{NaCl}$ concentrations. Potato plant produced longest shoot $(6.39 \mathrm{~cm})$ at control treatment (absence of $\mathrm{NaCl}$ ) followed by $30 \mathrm{mM} \mathrm{NaCl}(4.83 \mathrm{~cm})$ and $60 \mathrm{mM} \mathrm{NaCl}$ $(3.68 \mathrm{~cm})$. Shoot length drastically reduced to $1.87 \mathrm{~cm}$ at $90 \mathrm{mM} \mathrm{NaCl}$ and $1.55 \mathrm{~cm}$ at $120 \mathrm{mM} \mathrm{NaCl}$. The findings of [18] Sudhersan et al. (2012) were in strong conformity with our results they reported reduced shoot growth in potato in vitro due to salt stress by increasing salt concentration in MS media. Root length, the number of nodes per plantlet, the number of leaves per plantlet, the number of roots per plantlet and fresh weight were the highest $(8.00 \mathrm{~cm}, 6.96,9.01,4.96$ and $122.92 \mathrm{mg}$ respectively) in control treatment closely followed by $30 \mathrm{mM}$ and $60 \mathrm{mM} \mathrm{NaCl}$ levels. Most of the parameters reduced about $50 \%$ at $90 \mathrm{mM}$ of $\mathrm{NaCl}$ and were least at $120 \mathrm{mM} \mathrm{NaCl}$ level. Farhatullah et al. (2002) reported that even at $1 \% \mathrm{NaCl}$ in the media suppressed the root growth of the tested potato vari 


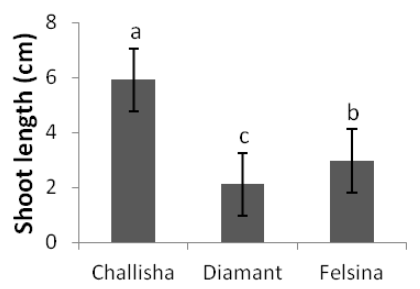

Cultivars name

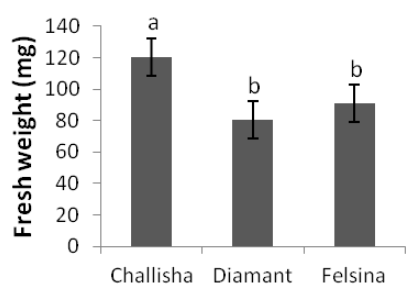

Cultivars name

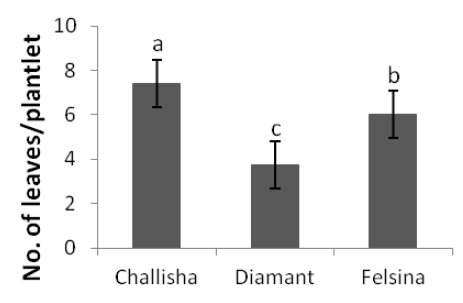

Cultivars name

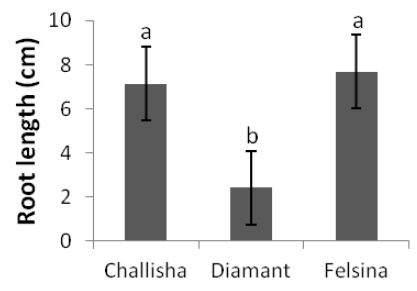

Cultivars name

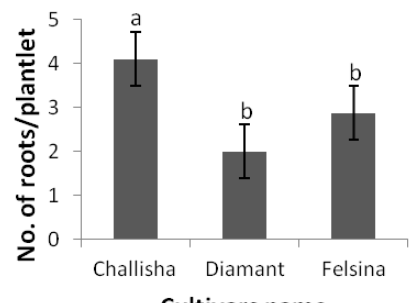

Cultivars name

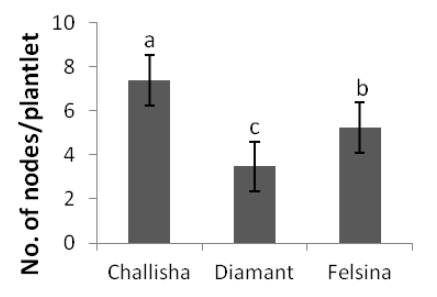

Cultivars name

Figure 1. The performance of Challisha is better than other cultivars in salt stress. Sprouted healthy tubers were selected as the primary source of explants and four weeks old in vitro plantlets of two nodal segments were transferred to MS media supplemented with various concentration of $\mathrm{NaCl}$. At the four weeks of culture, data were collected and analyzed statistically with the help of computer following STAT-C program. Different letters denote significant differences at the 95\% confidence level using Duncan's Multiple Range Test with four replications.

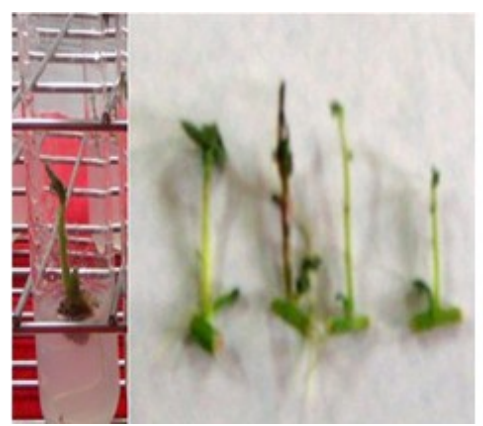

(a)

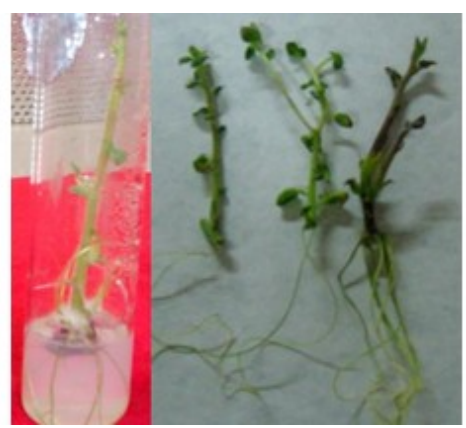

(b)

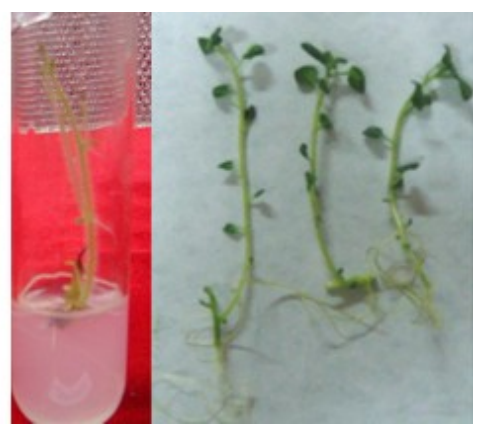

(c)

Figure 2. Response of three potato cultivars, Diamant (a), Felsina (b), and Challisha (c), under $\mathrm{NaCl}$ salt stress. The appearance of the variety also showed that performance of Challisha and Felsina are better than Diamant

eties [26]. $\mathrm{NaCl}$ at $100 \mathrm{mM}$ inhibited root growth in potato which was also agreement with our findings [15].

The growth of the potato cultivars in different parameters was significantly influenced by the interaction of cultivars and concentrations of $\mathrm{NaCl}$ (Table 2). The Longest shoot $(9.48 \mathrm{~cm})$ was found in $\mathrm{V}_{1} \mathrm{C}_{0}$, which was statistically similar to $\mathrm{V}_{1} \mathrm{C}_{1}(8.69 \mathrm{~cm})$ followed by $\mathrm{V}_{1} \mathrm{C}_{2}$
$(6.41 \mathrm{~cm})$ and $\mathrm{V}_{2} \mathrm{C}_{0}(5.59 \mathrm{~cm})$. The treatment combination $\mathrm{V}_{3} \mathrm{C}_{1}$ produced longest root $(10.24 \mathrm{~cm})$

which performed statistically similar to $\mathrm{V}_{1} \mathrm{C}_{2}, \mathrm{~V}_{3} \mathrm{C}_{0}$, $\mathrm{V}_{2} \mathrm{C}_{0}, \mathrm{~V}_{3} \mathrm{C}_{2}, \mathrm{~V}_{1} \mathrm{C}_{0}, \mathrm{~V}_{1} \mathrm{C}_{3}$ and $\mathrm{V}_{3} \mathrm{C}_{4}$. The number of nodes per plantlet was maximum in V1C1 (9.38) closely followed by $\mathrm{V}_{1} \mathrm{C}_{0}(9.25), \mathrm{V}_{1} \mathrm{C}_{2}(8.25)$ and $\mathrm{V}_{3} \mathrm{C}_{1}$ (7.88). The number of leaves per plantlet was the highest (10.63) in V1C0 which was statistically identical to 
$\mathrm{V}_{3} \mathrm{C}_{0}$ (9.28), $\mathrm{V}_{1} \mathrm{C}_{1}(8.50)$ and $\mathrm{V}_{1} \mathrm{C}_{2}$ (8.00). The treatment combination $\mathrm{V}_{1} \mathrm{C}_{0}$ produced the maximum number of roots per plantlet (7.13) which performed statistically identical to $\mathrm{V}_{2} \mathrm{C}_{0}$ (4.88) while $\mathrm{V}_{2} \mathrm{C}_{4}$ performed least. Fresh weight was the highest $(144.25 \mathrm{mg})$ in $\mathrm{V}_{1} \mathrm{C}_{0}$ which was statistically identical to $\mathrm{V}_{1} \mathrm{C}_{1}(138.25$ $\mathrm{mg}), \mathrm{V}_{1} \mathrm{C}_{2}(131.00 \mathrm{mg}), \mathrm{V}_{1} \mathrm{C}_{3}(107.25 \mathrm{mg}), \mathrm{V}_{2} \mathrm{C}_{0}$ $(101.00 \mathrm{mg}), \mathrm{V}_{3} \mathrm{C}_{0}(123.50 \mathrm{mg})$ and $\mathrm{V}_{3} \mathrm{C}_{1}(111.25 \mathrm{mg})$ while it was the lowest in $\mathrm{V}_{2} \mathrm{C}_{4}(47.50 \mathrm{mg})$. It was clear that the variety Cahallisha performed better up to 90 $\mathrm{mM} \mathrm{NaCl}$ in most of the parameters studied.

The physiological growth data were used to predict cultivars tolerance at higher salinity levels in vitro. [7] Zhang and Donnelly (1997), and [24] Aghaei et al. (2009) reported that the effect of salt stress on in vitro potato growth has been similar to that observed under field conditions. A significant correlation was found between in vitro growth and field performance. [27] Morpurgo (1991) also suggested in vitro screening of potato parental material for tolerance to salinity. Therefore, it appeared that salinity tolerance of potato genotypes could be successfully evaluated in vitro as a promising substitute for conventional field evaluations. There is merit in evaluation at a range of salinity levels since different genes are apparently expressed at various stress levels in vitro as observed in vivo in potato $[7,28]$. However, it is recommended to take more potato varieties for in vitro and in vivo micropropagation scheme. It could be used as a tool for the selection of broad tolerant to salt cultivars for field transplantation and also for designing breeding program.

\section{CONCLUSION}

Challisha, Diamant, and Felsina are survived well with exhibiting different growth status up to $60 \mathrm{mM}$ $\mathrm{NaCl}$, but they performed poorly at $120 \mathrm{mM}$ of $\mathrm{NaCl}$. Cultivar Challisha performed better regarding shoot length, root length, the number of nodes per plantlet and the fresh weight per plant up to $90 \mathrm{mM}$ of $\mathrm{NaCl}$. Thus, we can conclude that local indigenous variety Challisha is salt tolerant comparing with the modern cultivated varieties.

\section{ACKNOWLEDGMENT}

\section{REFERENCES}

1. Yokoi S, Bressan RA, Hasegawa, PM (2002) Salt Stress Tolerance of Plants. JIRCAS Working Report: 25-33.

2. Allakhverdiev SI, Sakamoto A, Nishiyama Y et al. (2000) Ionic and osmotic effects of $\mathrm{NaCl}$ induced inactivation of photosystems I and II Synechococcus sp. Plant Physiology 123: 1047-1056.

3. Munns R, Termaat A (1986) Whole-plant responses to salinity. Functional Plant Biology 13 (1): 143-160.

4. Marschner H (1995) Saline soils In: Mineral nutrition of higher plants. New York, Academic Press.

5. Romero-Aranda R, Syvertsen JP (1996) The influence of foliar applied urea nitrogen and saline solutions on net gas exchange of Citrus leaves. Journal of the American Society for Horticultural Science 121: 501-506.

6. Zaman MS, Ali GM, Muhammad A et al. (2015) In vitro screening of salt tolerance in potato (Solanum tuberosum L.) varieties. Sarhad Journal of Agriculture 31 (2): 106113. doi: /10.17582/journal.sja/2015/31.2.106.113.

7. Zhang YL, Donnelly DJ (1997) In vitro bioassays for salinity tolerance screening of potato. Potato Research 40: 285-295. doi: 10.1007/BF02358010.

8. Barnes WC, Peel TC (1958) The effect of various levels of salt in irrigation water on vegetable crops. Search Results Proceedings of the American Society for Horticultural Science 72: 339-342.

9. Bouaziz E (1980) Tolerance a la salure de la pomme de terre. Physiologie Vegetale 162: 11-17.

10. Paliwal KV, Yadav BR (1980) Effect of saline irrigation water on the yield of potato. International Journal of Agriculture Sciences 50: 1-33.

11. Levy D (1992) The response of potatoes (Solanum tuberosum L.) to salinity: Plant growth and tuber yields in the arid desert of Israel. Annals of Applied Biology 120: 547555.

12. Heuer B, Nadler A (1995) Growth and development of potatoes under salinity and water deficit. Australian Journal of Agricultural Research 46: 1477-1486.

13. Nadler A, Heuer B (1995) Effect of saline irrigation and water deficit on tuber quality. Potato Research 38: 19123.

14. Bilski JJ, Nelson DC, Conlon V (1988) The response of four potato cultivars to chloride salinity, sulphate salinity and calcium in pot experiments. American Journal of Potato Research 65: 85-90.

15. Naik PS, Widholm JM (1993) Comparison of tissue culture and whole plant responses to salinity in potato. Plant Cell Tissue Organ Culture 33: 273-280.

16. Etehadnia M (2009) Salt stress tolerance in potato genotypes. A Thesis submitted to the College of Graduate Studies and Research, University of Saskatchewan Saskatoon.

17. Bündig C, Vu TH, Meise P et al. (2016) Variability in osmotic stress tolerance of starch potato genotypes (Solanum tuberosum L.) as revealed by an in vitro screening: Role of proline, osmotic adjustment and drought re- 
sponse in pot. Journal of Agronomy and Crop Science doi:10.1111/jac.12186.

18. Sudhersan S, Manuel J, Ashkanani J, Al-Ajeel A (2012) In vitro screening of potato cultivars for salinity tolerance. American-Eurasian Journal of Sustainable Agriculture 6 (4): 344-348.

19. Munira S, Hossain MM, Zakaria M et al. (2015) Evaluation of potato varieties against salinity stress in Bangladesh. International Journal of Plant and Soil Science 6 (2): 73-81. doi: 10.9734/IJPSS/2015/15879.

20. Murshed R, Najla S, Albiski F, Kassem I, Jbour M, AlSaid H (2015) Using growth parameters for in-vitro screening of potato varieties tolerant to salt stress. Journal of Agricultural Science and Technology 17 (2): 483-494.

21. Mass EV, Hoffman GKJ (1977) Crop salt tolerance-current assessment. Journal of Irrigation and Drainage Engineering 103 (2): 115-134.

22. Sabbah S, Tal M (1990) Development of callus and suspension cultures of potato resistant to $\mathrm{NaCl}$ and mannitol and their response to stress. Plant Cell, Tissue and Organ Culture 21: 119-128.

23. Murashige T, Skoog F (1962) A revised medium for rapid growth and bioassays with tobacco tissue cultures. Physiology Plant 15: 473-497.

24. Aghaei KA, Ehsanpour A, Komatsu S (2009) Potato responds to salt stress by increased activity of antioxidant enzymes. Journal of Integrative Plant Biology 51 (2): 1095-1103. doi: 10.1111/j.1744-7909.2009.00886.x.

25. Rahman MH, Islam R, Hossain M, Haider SA (2008) Differential response of potato under sodium chloride stress in vitro. Journal of Bio-Science 16: 79-83. doi: 10.3329/jbs.v16i0.3745.

26. Farhatullah R, Mehmood, Raziuddin (2002) In vitro effect on the vigor of potato plantlets. Biotechnology 1: 73-77. doi:10.3923/biotech.2002.73.77.

27. Morpurgo R (1991) Correlation between potato clones grown in vivo and in vitro under sodium chloride stress conditions. Plant Breeding 107: 80-82. doi: 10.1111/j.1439-0523.1991.tb00532.x.

28. Tal M (1994) In vitro selection for salt tolerance in crop plants: Theoretical and practical considerations. In Vitro Plant: Cellular and Developmental Biology 30 (4): 175180. doi: 10.1007/BF02823028. 